\title{
Gender Differences in Managerial Behavior and Their Leadership Styles
}

\author{
Rugiatou JALLOW \\ Istanbul Aydin University, Institute of Graduate Studies \\ Department of Business Administration
}

\begin{abstract}
This study investigated gender differences in relation to managerial behavior and leadership styles in The Gambia. The correlation between leadership styles and managerial behavior was firstly examined while gender differences and leadership styles were investigated. However, quantitative method was used to gather information from the target audience where Mann-Whitney analysis, crosstabsanalysis and correlation analysis were employed as the estimation techniques. From the analysis, the findings reported that female has the highest frequency in terms of transformational style of management and male has the highest frequency in terms of transactional leadership style in an organization. The study concluded that male leaders are mostly recognized in the managerial positions compared to female leaders.
\end{abstract}

Keywords: Gender, Managerial Behavior, Leadership, Transactional And Transformational Style

\section{INTRODUCTION}

Most of the studies on gender distinctions and similarities in leadership positions wereoriginally motivated by the lack of women in heading businesses and political positions. This has been prompted scholars in the literature as to whether female and male executives use the identical or distinct leadership styles. Though female have made huge progress in achieving strategic leadership within corporate firms and government parastatals, yet they are underrepresented at the toppositions (Kent, Blair, Rudd, \& Schuele, 2010).In a study conducted by Park (1996), male gender qualities are classified as; competitive, confident, sensible, intellectual, proactive, optimistic, persuasive, creative, opportunistic and impersonal, these qualities are distinct from the female gender qualities which are outlined as; compassionate, responsive, articulate, cooperative, intelligent, pleasant, sincere, reactive to ideas, jovial, soft, compassion, reasonable and submissive. However, leadership is described as the act of being responsible for other people in several ways, including motivation, reward and punish, organization, and the inspiration of followers. Leaders have formal power over followers, though Gorska(2016) opined that, it is uncertainly true to differentiate leadership from management by distinguishing managers as those in charge of formal organization and task control, whereby leaders are defined as those who set new directions, inspire people and adapt to changes.Leadership is neither a rank nor a position, leadership is an attitude as well as action. It can be most suitably described as the act of influencing in which one individual can support others in the attainment of a common goal or objective. There continues to be a discussion in progress on whether leaders are "born or made".Despite the efforts to advance women into the management ranks of organizations, representations of women in executive positions is still lacking. Meanwhile, some believe that women bring unique and effective leadership behaviors to the workplace while some castigate it, indicating an inconclusive outcome from the previous writers. However, this prompts the current research to aim to understand the similarities and differences in leadership behaviors of executive women and executive men, and to further examine the leadership skills that women need to display to be successful in executive roles.

$>$ Specific Objectives

- To examine the relationship between leadership styles and managerial behavior

- To investigate gender differences in managerial behavior

> Hypothesis

- Ho1: There is no significant relationship between leadership styles and managerial behavior

- Ho2: There is no significant gender differences in managerial behavior

\section{LITERATURE REVIEW}

Leadership is not a person or a position, it is a building moral relationship between people, based on trust, obligation, commitment, emotion and a shared vision of the good. Leadership is the act of setting purpose or direction for followers and get them move along towards that direction with competence and full commitment.If your actions inspire and influence others to dream more, lean more, do more and become more, then you are a leader (Kadyrkulova, 2018).Gibson (1995) investigated a research on gender disparities in leadership among four nations. A panel data was used and subjected to various analysis such as Wilk's test, F-stat, MANOVA, and ANOVA. The results reported that males insist the aspect of the goal setting, whereas females prioritize the facilitation aspect of interaction.Carless (1998) wrote on gender disparities and leadership transformational in Australia using descriptive and inter correlation analysis. The study found that women managers exhibit more transformational role compared to men. Oshagbemi and Gill (2003) wrote the disparities and similarities of gender in the leading role among UK 
managers. They used 2 tailed t-test method and discovered that male leaders delegate more task than the female leaders and the difference in their leading role is not significant. Melero (2004) conducted a survey on sex differences in the style of the management in Germany. The findings indicated that work environment wherewomen's role is being enhanced,the management is influenced democratically, better collaborative and active managerial partnerships among staff. Afolabi, Obude, Okediji and Ezeh (2009) studied the connection between gender and leadership in relation to commitment and performance of the employee in Nigeria. they employed 2-way ANOVA and reported that democratic female leaders instigate higher performance while autocratic female leaders influence commitment.

Kent, Blair, Rudd and Schuele (2010) wrote on the connection between gender differences and transformational behavior of the leaders in Germany. They employed descriptive and ANOVA analyses and showed that gender leading behaviors appear the same. Paustian-Underdahl, Wlker and Woehr (2014) conducted a survey on gender and leadership effectiveness using meta-analysis contextual. The study reported that females are more significant than the males.Walker (2015) examined leadership perception in relation to gender and employee motivation. The study used ANOVA technique and found that gender and style of leadership have no significant influence on employee motivation. Thna and Jayatilake (2016) evaluated gender influences on leadership styles in Sri Lanka. The statistical tests reported that gender managerial role in government has no significant difference. Mushtaq (2016) investigated an empirical review of the connection between gender and leadership style and found gender makes no one a good leader though skills differ. Süer (2017) wrote on leadership effects on employees' empowerment and gender role in Turkey. Descriptive analysis, correlation and regression analysis were used in the study, and reported that transformational style is the main imperative indicator to employee's empowerment.Sebastian and Moon (2018) studied the gender disparities in leadership participatory among school principals working time with others in United States. The study employed hierarchical linear modeling and found that woman principals used more time with others compared to their male counterparts.

\section{METHODOLOGY}

This research employed a convenient sampling among the employees in The Gambia state capital. A set of questionnaires were distributed to 250 employees though provision was made for the wrongly filled questions or unwillingly given information. Nonetheless, a total of 200 individualquestionnairewas returned completely. The study used correlation analysis, andMann-Whitney analysis and crosstabs analysis as the estimation techniques.

\section{Model Specification}

In order to achieve the relationship between the variables: gender differences, managerial behavior, and leadership style, a simultaneous modeling was set up linking the three variables. The models are presented below as:

TLS $=\mathrm{f}(\mathrm{TSLS}$, PLS, MB)

TSLS $=\mathrm{f}(\mathrm{TLS}, \mathrm{PLS}, \mathrm{MB})$

PLS $=\mathrm{f}(\mathrm{TLS}, \mathrm{TSLS}, \mathrm{MB})$

$\mathrm{MB}=\mathrm{f}(\mathrm{TLS}, \mathrm{TSLS}$, PLS $)$

Where

TLS = Transformational Leadership Style

TSLS = Transactional Leadership Style

PLS = Passive Leadership Style

$\mathrm{MB}=$ Managerial Behavior

However, correlation test was established in order to determine the relationship between the stated variables.

\section{Correlation Analysis}

\begin{tabular}{|c|c|c|c|c|c|}
\hline \multicolumn{6}{|c|}{ Table 1: Correlations } \\
\hline & & $\begin{array}{l}\text { Transformational } \\
\text { Leadership Style }\end{array}$ & $\begin{array}{c}\text { Transactional } \\
\text { Leadership Style }\end{array}$ & $\begin{array}{c}\text { Passive } \\
\text { Leadership Style }\end{array}$ & $\begin{array}{c}\text { Managerial } \\
\text { Behavior }\end{array}$ \\
\hline \multirow{3}{*}{$\begin{array}{l}\text { Transformational } \\
\text { Leadership Style }\end{array}$} & Pearson Correlation & 1 & $.599^{* *}$ & $-.635^{* *}$ & $.593^{* *}$ \\
\hline & Sig. (2-tailed) & & .000 & .000 & .000 \\
\hline & & & & & \\
\hline \multirow{2}{*}{$\begin{array}{c}\text { Transactional } \\
\text { Leadership Style }\end{array}$} & Pearson Correlation & $.599^{* *}$ & 1 & $-.637^{* *}$ & $.475^{* *}$ \\
\hline & Sig. (2-tailed) & .000 & & .000 & .000 \\
\hline \multirow{3}{*}{$\begin{array}{l}\text { Passive Leadership } \\
\text { Style }\end{array}$} & Porcon Corrolotion & $635^{* *} *$ & $637^{* * *}$ & 1 & $484^{* *}$ \\
\hline & Pearson Correlauon & -.053 & -.031 & 1 & -.484 \\
\hline & & & & & \\
\hline \multirow{3}{*}{ Managerial Behavior } & Pearson Correlation & $.593^{* *}$ & $.475^{* *}$ & $-.484^{* *}$ & 1 \\
\hline & Sig. (2-tailed) & .000 & .000 & .000 & \\
\hline & & & & & \\
\hline
\end{tabular}


The report of the correlation analysis presented in the above table shows the correlation coefficient value between transformational leadership style (TLS) and transactional leadership style (TSLS) is 0.599 and its 2-tailed sig value of 0.000 representing that a positive significant relationship existing between TLS and TSLS respectively. Transformational leadership style and passive leadership style show a correlation coefficient value of -0.635 with sig value 0.000 , indicating that TLS and PLS have a negative significant correlation between each other. The transformational leadership style (TLS) and managerial behavior (MB) reveal a correlation coefficient value of 0.593 with 2-tailed sig value of 0.000 , implying that TLS and $\mathrm{MB}$ show a positive and significant relationship to one another. Meanwhile, passive leadership style (PLS) reveals a negative and significant relationship with transactional leadership style and managerial behavior.

\section{Crosstabs Analysis}

Gender Differences on Transformational Leadership Style, Transactional Leadership Style, Passive Leadership Style, and Managerial Behavior

1: Not at all, 2: Once in a while, 3: Sometimes, 4: Fairly often, and 5: Frequently if not always.

Mann-Whitney Analysis

Table 2:Transformationalleadershipstyle on Gender

\begin{tabular}{|c|c|c|c|c|c|c|}
\hline \multirow[t]{4}{*}{$\begin{array}{c}\text { Mean of Transformational } \\
\text { Leadership Style }\end{array}$} & $\begin{array}{l}\text { Gender } \\
\text { Status }\end{array}$ & $\mathbf{N}$ & Mean Rank & Sum of Ranks & $\mathbf{Z}$ & Sig. \\
\hline & Male & 113 & 61.59 & 6960.00 & \multirow[t]{3}{*}{-10.87} & \multirow[t]{3}{*}{.00} \\
\hline & Female & 87 & 151.03 & 13140.00 & & \\
\hline & Total & 200 & & & & \\
\hline
\end{tabular}

Source: Researcher's compilation

The mean rank value of male is lower than female value as shown in the above table. The value of $\mathrm{Z}$ is -10.87 with the $\mathrm{p}$ value of .00 that is less than of 0.05 . Therefore, it can be decided that male and female have different transformational leadership style in The Gambia.

Table 3:Transactionalleadershipstyle on Gender

\begin{tabular}{|c|c|c|c|c|c|c|}
\hline \multirow{3}{*}{$\begin{array}{c}\text { Mean of } \\
\text { Transactional } \\
\text { Leadership Style }\end{array}$} & Gender Status & N & Mean Rank & Sum of Ranks & Z & Sig. \\
\cline { 2 - 6 } & Male & 113 & 63.58 & 7185.00 & -10.49 & \\
\cline { 2 - 6 } & Female & 87 & 148.45 & 12915.00 & \\
\cline { 2 - 6 } & Total & 200 & & & \\
\hline
\end{tabular}

Source: Researcher's compilation

The mean value of male is less than female value as shown in the above table. The value of $\mathrm{Z}$ is -10.49 with the $\mathrm{p}$-value of .00 that is less than of 0.05 . Therefore, it can be decided that male and female have different transactional leadership style in The Gambia.

Table 4:Mann-Whitney test forPassiveleadershipstyle on Gender

\begin{tabular}{|c|c|c|c|c|c|c|}
\hline \multirow{3}{*}{$\begin{array}{c}\text { Mean of Passive } \\
\text { Leadership Style }\end{array}$} & Gender Status & N & Mean Rank & Sum of Ranks & Z & Sig. \\
\cline { 2 - 6 } & Male & 113 & 59.60 & 6735.00 & -11.52 & \\
\cline { 2 - 6 } & Female & 87 & 153.62 & 13365.00 & \\
\cline { 2 - 6 } & Total & 200 & & & \\
\hline
\end{tabular}

Source: Researcher's compilation

The mean rank value of male is 59.60 that is lower than female rank value of 153.62 as shown in the below table. The value of $\mathrm{Z}$ is -11.52 with the p-value of .00 that is lower than of 0.05 . Therefore, null hypothesis is rejected, while alternative hypothesis is accepted. it can be agreed that male and female have different passive leadership style in The Gambia. 
Table 5: Managerialbehavior on Gender

\begin{tabular}{|c|c|c|c|c|c|c|}
\hline $\begin{array}{c}\text { Mean of } \\
\text { Managerial } \\
\text { Behavior }\end{array}$ & $\begin{array}{c}\text { Gender } \\
\text { Status }\end{array}$ & N & Mean Rank & Sum of Ranks & Z & Sig. \\
\cline { 2 - 5 } & Male & 113 & 94.79 & 113 & -1.60 & .10 \\
\cline { 2 - 5 } & Female & 87 & 107.92 & 87 & \\
\cline { 2 - 5 } & Total & 200 & & & \\
\hline
\end{tabular}

Source: Researcher's compilation

The mean value of male is lowerthan female value as shown in the below table. The value of $\mathrm{Z}$ is -1.60 with the p-value of .10 that is above 0.05 but can be accepted at $10 \%$. Therefore, it can be decided that male and female have different managerial behavior in The Gambia.

\section{Crosstabs Analysis}

\begin{tabular}{|c|c|c|c|c|c|c|c|}
\hline \multicolumn{8}{|c|}{ Table 1: Gender * Transformational Leadership Style Crosstabulation } \\
\hline & & \multicolumn{5}{|c|}{ Transformational Leadership Style } & \multirow[t]{2}{*}{ Total } \\
\hline & & 1 & 2 & 3 & 4 & 5 & \\
\hline \multirow{2}{*}{ Gender } & Male & 2 & 3 & 14 & 59 & 64 & 142 \\
\hline & Female & 0 & 1 & 2 & 30 & 25 & 58 \\
\hline \multicolumn{2}{|c|}{ Total } & 2 & 4 & 16 & 89 & 89 & 200 \\
\hline
\end{tabular}

Source: Researcher's compilation

Table 6 reveals gender differences as against transformational leadership style and it shows that 2 male chose not all, 3 male chose once in a while, 14 male chose sometimes, 59 male chose fairly often and 64 male chose frequently, if not often that male is transformational while 1 female chose once in a while, 2 female chose sometimes, 30 female chose fairly often and 25 female chose frequently if not always that female is more transformational compared to male. This shows that male has the frequency value as against the female, indicating that male has the highest frequency in terms of transformational style of management.

\begin{tabular}{|c|c|c|c|c|c|c|c|}
\hline \multicolumn{2}{|c|}{ Table 2: Gender * Transactional Leadership Style Crosstabulation } \\
\hline \\
\cline { 3 - 8 } \multicolumn{2}{|c|}{} & \multicolumn{7}{c|}{ Transactional Leadership Style } & 4 & 5 & \multicolumn{2}{c|}{ Total } \\
\hline \multirow{2}{*}{ Gender } & 1 & 1 & 2 & 3 & 46 & 63 & 142 \\
\cline { 2 - 9 } & 2 & 0 & 3 & 28 & 26 & 18 & 58 \\
\hline \multicolumn{2}{|c|}{ Total } & 2 & 7 & 38 & 72 & 81 & 200 \\
\hline
\end{tabular}

Source: Researcher's compilation

The above table shows gender differences as against transactional leadership style and it shows that 2 male chose not all, 3 male chose once in a while, 28 male chose sometimes, 46 male chose fairly often and 63 male chose frequently, if not often that male is transformational while 4 female chose once in a while, 10 female chose sometimes, 26 female chose fairly often and 18 female chose frequently if not always that females are more transactional leaders compared to male. This shows that male has the highest frequency value as against the female, indicating that male has the highest frequency in terms of transactional leadership style in an organization.

\begin{tabular}{|c|c|c|c|c|c|c|c|}
\hline \multicolumn{8}{|c|}{ Table 3: Gender * Passive Leadership Style Crosstabulation } \\
\hline & & \multicolumn{5}{|c|}{$\begin{array}{l}\text { Passive Leadership Style } \\
\end{array}$} & \multirow[t]{2}{*}{ Total } \\
\hline & & 1 & 2 & 3 & 4 & 5 & \\
\hline \multirow{2}{*}{ Gender } & 1 & 65 & 66 & 5 & 3 & 3 & 142 \\
\hline & 2 & 27 & 25 & 4 & 2 & 0 & 58 \\
\hline \multicolumn{2}{|c|}{ Total } & 92 & 91 & 9 & 5 & 3 & 200 \\
\hline
\end{tabular}

Source: Researcher's compilation

Table 8 reveals gender differences as against transformational leadership style and it shows that 65 male chose not all, 66 male chose once in a while, 5 male chose sometimes, 3 male chose fairly often and 3 male chose frequently, if not often that male is passive while 27 female chose not at all, 25 female chose once in a while, 4 female chose sometimes and 2 female chose fairly often that female is more passive compared to male. This shows that male and female are not passive leaders though male has the higher variation compared to female. 
ISSN No:-2456-2165

\begin{tabular}{|c|c|c|c|c|c|c|c|}
\hline \multicolumn{8}{|c|}{ Table 4: Gender * Managerial Behavior Crosstabulation } \\
\hline & & \multicolumn{5}{|c|}{ Managerial Behavior } & \multirow[t]{2}{*}{ Total } \\
\hline & & 1 & 2 & 3 & 4 & 5 & \\
\hline \multirow{2}{*}{ Gender } & 1 & 5 & 3 & 16 & 54 & 64 & 142 \\
\hline & 2 & 0 & 3 & 5 & 24 & 26 & 58 \\
\hline \multicolumn{2}{|c|}{ Total } & 5 & 6 & 21 & 78 & 90 & 200 \\
\hline
\end{tabular}

Source: Researcher's compilation

Table 9 reveals gender differences as against managerial behavior and it shows that 5 male chose not at all, 3 male chose once in a while, 16 male chose sometimes, 54 male chose fairly often and 64 male chose frequently, if not often that male is managerial while 3 female chose once in a while, 5 female chose sometimes, 24 female chose fairly often and 26 female chose frequently if not always that female is more managerial compared to their counterpart. This shows that male has the frequency value as against the female, indicating that male has the highest frequency in terms of managerial behavior.

\section{CONCLUSION}

Literature and this current study suggest that leadership may be influenced by gender, where women act in more supportive ways giving subordinates more freedom, less supervision, and are more understating and tolerant. Moreover, they treat rewards as motivational tool and organize work, women tend to be more democratic when holding leadership positions. It concluded that a positive significant relationship existing between transactional style and transformational style, transformational leadership style and passive leadership style have a negative significant correlation between, transformational leadership style and managerial behavior show a positive and significant relationship to one another while passive leadership style (PLS) reveals a negative and significant relationship with transactional leadership style and managerial behavior. The study also concluded that male leaders are mostly recognized as the managerial positions compared to female leaders.

\section{REFERENCES}

[1]. Afolabi, Obude, Okediji and Ezeh (2009).Influence of Gender and Leadership Style onCareer Commitment and Job Performance ofSubordinates.Global Journal of Humanities, 7(182), 1-8.

[2]. Carless (1998).Gender Differences in TransformationalLeadership: An Examination of Superior,Leader, and Subordinate Perspectives. Sex Roles. 39(11/12), 887-902.

[3]. Gibson, C. B. (1995). An Investigation of Gender Differences inLeadership across Four Countries.Journal of International business Studies, Second Quarter1, 255-279.

[4]. Kent, T. W., Blair, C. A., Rudd, H. F., \&Schuele, U. (2010).Gender Differences and Transformational Leadership Behavior: Do Both German Men and Women Lead in the Same Way?International journal of Leadership Studies, 6(1), 52-66.
[5]. Melero, E. (2004). Sex Differences in Managerial Style: From IndividualLeadership to Organizational Labour Relationships. Discussion Paper, Institute of the Study of Labor.

[6]. Mushtaq A. (2016). Gender and Leadership Styles: AConceptual Framework for Analysis. International Journal of Business Quantitative Economics and Applied Management Research, 2(10), 19-31.

[7]. Paustian-Underdahl, S. C., Wlker, L. S., \&Woehr, D. J. (2014). Gender and Perceptions of Leadership Effectiveness: A Meta-Analysis ofContextual Moderators. Journal of Applied Psychology, 99(6), 1129-1145

[8]. Oshagbemi, T., \& Gill, R. (2003).Gender differences and similarities in the leadership styles and behavior of UKmanagers.Women in Management Review, 18(6), 288-298, https://doi.org/10.1108/09649420310491468.

[9]. Thna, K. D., \&Jayatilake, L. V. (2016).Influence of Gender on Leadership Styles andEffectiveness of Leader - (Study Based on GovernmentUniversity Administrative Staff of Sri Lanka).International Journal of Scientific Research and Innovative Technology, 3(8), 63-80.

[10]. Sebastian, J., \& Moon, J. (2018).Gender Differences in Participatory Leadership:An Examination of Principals' Time SpentWorking with Others. International Journal of Education Policy \& Leadership, 12(8), 1-16.

[11]. Süer, C.,(2017). The effect of leadership styles on employees' psychological empowerment and the gender role in this relation. Research Journal of Business and Management (RJBM),.4(4), 434-446.

[12]. Walker, K. M. (2015). Perceptions of Leadership: Impact of Leadership Style and Gender on EmployeeMotivation. Master's thesis.Walden University. Retrieved from https://scholarworks.waldenu.edu/dissertations 